\title{
Acute and Severe Hypercalcemia in a Near-Drowning Victim
}

\author{
Tomoaki Takata $^{1,2^{*}}$, Akihisa Nakaoka ${ }^{1}$, Kazuhiro Kato ${ }^{1}$, Takeaki Fukui ${ }^{2}$, Satoko Maeta ${ }^{2}$, \\ Chishio Munemura ${ }^{2}$, Yoshikazu Murawaki ${ }^{2}$
}

${ }^{1}$ Department of Internal Medicine, Sanin Rosai Hospital, Yonago, Japan; ${ }^{2}$ Division of Medicine and Clinical Science, Tottori University School of Medicine, Yonago, Japan.

Email: ${ }^{*}$-takata@med.tottori-u.ac.jp

Received August $14^{\text {th }}, 2013$; revised September 12 ${ }^{\text {th }}, 2013$; accepted September $29^{\text {th }}, 2013$

Copyright (C) 2013 Tomoaki Takata et al. This is an open access article distributed under the Creative Commons Attribution License, which permits unrestricted use, distribution, and reproduction in any medium, provided the original work is properly cited.

\begin{abstract}
An 80-year-old male was admitted to our hospital because of near-drowning in a hot spring. Besides hypoxia, serum calcium was extremely high at $15.5 \mathrm{mg} / \mathrm{dL}$ on admission. After the treatment with normal saline infusion, furosemide and calcitonin, the hypercalcemia was transient and didn't recur during the course. The hot spring water contained much calcium, so his hypercalcemia was considered to be a result of calcium absorption mainly through the alveoli. In this case, we revealed that serum calcium rose within a short time after drowning, suggesting the necessity to measure the calcium concentration of the drowning fluid in a near-drowning victim.
\end{abstract}

Keywords: Hypercalcemia; Drowning; Hot Spring

\section{Introduction}

Drowning is a life-threatening accident and care of hypoxia is the mainstay of therapy. The constitution of the aspirated water has rarely been considered to be important, except for the difference between sea-water and fresh water. Electrolyte disability in near-drowning victim has been a rare complication and has been considered to seldom need treatment. On the other hand, there are a few cases of lethal hypercalcemia complicating a neardrowning in unusual circumstances such as in the Dead Sea [1]. We report a case of severe hypercalcemia complicating a near-drowning in a hot spring.

\section{Case Report}

An 80-year-old male was admitted to our hospital. He has a past history of hypertension and ventriculoperitoneal shunt after subarachnoid hemorrhage. His regular medications were famotidine, olmesartan, and amlodipine. He was found drowning in a hot spring. He was breathing by himself when rescued and transferred to our hospital 22 minutes later.

When arriving, he was conscious but disoriented. His body weight was $65 \mathrm{~kg}$. His body temperature was $38.6^{\circ} \mathrm{C}$, the pulse rate was 122 beat per minute and regu-

"Corresponding author. lar, blood pressure was 206/110 $\mathrm{mmHg}$, and his saturation of oxygen was $88 \%$ while receiving $15 \mathrm{~L} / \mathrm{min}$ oxygen by reservoir mask. His skin was wet. Auscultation of the chest revealed coarse crackles at both lungs. No neurologic dysfunction was seen.

An electrocardiograph, chest radiograph, and blood tests were performed at the emergency room. The electrocardiograph revealed heart rate of 115 beat per minute with multiple premature ventricular contraction and premature atrial contraction. The QT interval corrected for heart rate was 0.404 second. The chest radiograph showed bilateral congestion (Figure 1). Laboratory data (Table 1) of the blood revealed white blood count of $9800 / \mu \mathrm{L}$, neutrophil of $32.7 \%$, hematocrit of $42.8 \%$, hemoglobin of $14.3 \mathrm{~g} / \mathrm{dL}$, platelet of $316 \times 10^{3} / \mu \mathrm{L}$, sodium of $137 \mathrm{mEq} / \mathrm{L}$, potassium of $3.7 \mathrm{mEq} / \mathrm{L}$, chloride of 104 $\mathrm{mEq} / \mathrm{L}$, calcium $(\mathrm{Ca})$ of $15.5 \mathrm{mg} / \mathrm{dL}$, phosphorus of 4.0 $\mathrm{mg} / \mathrm{dL}$, blood urea nitrogen of $15.5 \mathrm{mg} / \mathrm{dL}$, creatinine $(\mathrm{Cr})$ of $0.95 \mathrm{mg} / \mathrm{dL}$, total protein of $7.8 \mathrm{~g} / \mathrm{dL}$, albumin of 4.3 $\mathrm{g} / \mathrm{dL}$, asparate aminotransferase of $29 \mathrm{IU} / \mathrm{L}$, alanine aminotransferase of $15 \mathrm{IU} / \mathrm{L}$, lactate dehydrogenase of $266 \mathrm{IU} / \mathrm{L}$, creatine kinase of $138 \mathrm{IU} / \mathrm{L}$, and blood glucose of $150 \mathrm{mg} / \mathrm{dL}$. Arterial blood gas analysis without receiving any oxygen revealed $\mathrm{pH}$ of $7.289, \mathrm{pCO}_{2}$ of 55.0 $\mathrm{mmHg}, \mathrm{pO}_{2}$ of $27.2 \mathrm{mmHg}, \mathrm{HCO}_{3}^{-}$of $25.5 \mathrm{mmol} / \mathrm{L}$, $\mathrm{BE}$ of $-1.6 \mathrm{mmol} / \mathrm{L}$, ionized $\mathrm{Ca}$ of $3.94 \mathrm{mEq} / \mathrm{L}$, and 


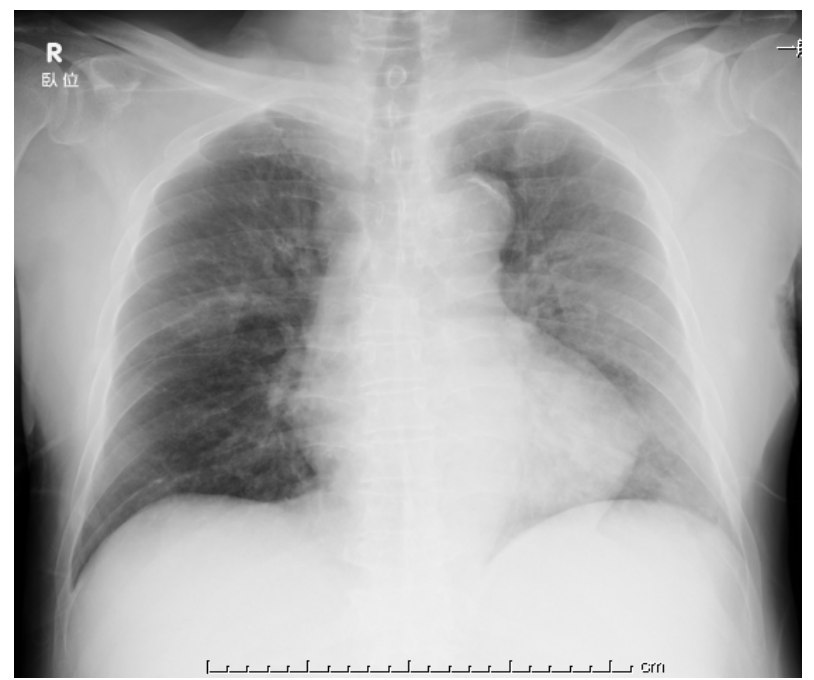

Figure 1. Chest radiograph showed bilateral congestion.

Table 1. Laboratory findings on admission.

\begin{tabular}{|c|c|c|c|}
\hline \multicolumn{3}{|c|}{ Complete blood count } & \\
\hline WBC & 9800 & $/ \mu \mathrm{L}$ & \\
\hline neu & 32.7 & $\%$ & \\
\hline $\mathrm{RBC}$ & $473 \times 10^{4}$ & $/ \mu \mathrm{L}$ & \\
\hline $\mathrm{Ht}$ & 42.8 & $\%$ & \\
\hline $\mathrm{Hb}$ & 14.3 & $\mathrm{~g} / \mathrm{dL}$ & \\
\hline PLT & $316 \times 10^{3}$ & $/ \mu \mathrm{L}$ & \\
\hline \multicolumn{4}{|c|}{ Blood chemistory } \\
\hline $\mathrm{Na}$ & 137 & $\mathrm{mEq} / \mathrm{L}$ & \\
\hline K & 3.7 & $\mathrm{mEq} / \mathrm{L}$ & \\
\hline $\mathrm{Cl}$ & 104 & $\mathrm{mEq} / \mathrm{L}$ & \\
\hline $\mathrm{Ca}$ & 15.5 & $\mathrm{mg} / \mathrm{dL}$ & \\
\hline $\mathrm{P}$ & 4.0 & $\mathrm{mg} / \mathrm{dL}$ & \\
\hline BUN & 15.5 & $\mathrm{mg} / \mathrm{dL}$ & \\
\hline $\mathrm{Cr}$ & 0.95 & $\mathrm{mg} / \mathrm{dL}$ & \\
\hline TP & 7.8 & $\mathrm{~g} / \mathrm{dL}$ & \\
\hline Alb & 4.3 & $\mathrm{~g} / \mathrm{dL}$ & \\
\hline AST & 29 & $\mathrm{IU} / \mathrm{L}$ & \\
\hline ALT & 15 & $\mathrm{IU} / \mathrm{L}$ & \\
\hline LDH & 266 & $\mathrm{IU} / \mathrm{L}$ & \\
\hline $\mathrm{CK}$ & 138 & $\mathrm{IU} / \mathrm{L}$ & \\
\hline Glucose & 150 & $\mathrm{mg} / \mathrm{dL}$ & \\
\hline \multicolumn{4}{|c|}{ Arterial blood gas (room air) } \\
\hline $\mathrm{pH}$ & 7.289 & & \\
\hline $\mathrm{pCO}_{2}$ & 55.0 & $\mathrm{mmHg}$ & \\
\hline $\mathrm{pO}_{2}$ & 27.2 & $\mathrm{mmHg}$ & \\
\hline $\mathrm{HCO}_{3}^{-}$ & 25.5 & $\mathrm{mmol} / \mathrm{L}$ & \\
\hline $\mathrm{BE}$ & -1.6 & $\mathrm{mmol} / \mathrm{L}$ & \\
\hline $\mathrm{Ca}^{2+}$ & 3.94 & $\mathrm{mEq} / \mathrm{L}$ & \\
\hline Lactate & 21.0 & $\mathrm{mg} / \mathrm{dL}$ & \\
\hline \multicolumn{3}{|c|}{ Tumor markers and endocrine studies } & (normal range) \\
\hline intact PTH & 12 & $\mathrm{pg} / \mathrm{mL}$ & $(10-65)$ \\
\hline PTH-rP & $<1.0$ & $\mathrm{pmol} / \mathrm{L}$ & $(<1.1)$ \\
\hline $1,25-(\mathrm{OH})_{2} \mathrm{D}_{3}$ & 32.1 & $\mathrm{pg} / \mathrm{mL}$ & $(20-60)$ \\
\hline calcitonin & 77 & $\mathrm{pg} / \mathrm{mL}$ & $(15-86)$ \\
\hline $\mathrm{ACE}$ & 5.1 & $\mathrm{U} / \mathrm{L}$ & $(8.3-21.4)$ \\
\hline SCC & 6.1 & $\mathrm{pg} / \mathrm{mL}$ & $(<1.5)$ \\
\hline CYFRA & 5.8 & $\mathrm{ng} / \mathrm{mL}$ & $(<3.5)$ \\
\hline NSE & 12.7 & $\mathrm{ng} / \mathrm{mL}$ & $(<10)$ \\
\hline
\end{tabular}

lactate of $21.0 \mathrm{mg} / \mathrm{dL}$. Computed tomography (CT) of head to abdomen revealed low density area at right caudate nucleus and pulmonary congestion at both lungs. No tumor or lymphadenopathy was detected.

He was admitted to our intensive care unit. Arterial blood gas analysis while receiving $15 \mathrm{~L} / \mathrm{min}$ oxygen by reservoir mask at 30 minutes after his arrival revealed $\mathrm{pH}$ of $7.305, \mathrm{pCO}_{2}$ of $51.7 \mathrm{mmHg}, \mathrm{pO}_{2}$ of $64.1 \mathrm{mmHg}$, $\mathrm{HCO}_{3}^{-}$of $24.9 \mathrm{mmol} / \mathrm{L}, \mathrm{BE}$ of $-1.7 \mathrm{mmol} / \mathrm{L}$, ionized $\mathrm{Ca}$ of $4.36 \mathrm{mEq} / \mathrm{L}$, lactate of $15.0 \mathrm{mg} / \mathrm{dL}$. He was intubated and mechanical ventilation with high PEEP was performed for his respiratory failure, then nasogastric tube was inserted and approximately $540 \mathrm{~mL}$ of fluid was aspirated.

The serum Ca was extremely high, thus normal saline injection was initiated and subsequently intravenous furosemide and intramuscular calcitonin 40 IU per 12 hours were administered. The ionized $\mathrm{Ca}$ level rose to $4.38 \mathrm{mEq} / \mathrm{L}$ after two hours of his admission. The second hospital day, 12 hours after admission, the laboratory data showed serum $\mathrm{Ca}$ of $13.2 \mathrm{mg} / \mathrm{dL}$, magnesium of 1.6 $\mathrm{mg} / \mathrm{dL}$ and $\mathrm{Cr}$ of $1.42 \mathrm{mg} / \mathrm{dL}$. The third hospital day, 36 hours after admission, the laboratory data showed serum $\mathrm{Ca}$ of $9.6 \mathrm{mg} / \mathrm{dL}$ and $\mathrm{Cr}$ of $1.55 \mathrm{mg} / \mathrm{dL}$. Analysis of the $1470 \mathrm{~mL}$ of urine from up to 12 hours of his admission revealed $\mathrm{Ca}$ of $13.7 \mathrm{mg} / \mathrm{dL}$. His respiratory failure improved and intratracheal tube was removed on the fifth hospital day. The serum $\mathrm{Cr}$ was normalized at 0.65 $\mathrm{mg} / \mathrm{dL}$ on the sixth hospital day. The hypercalcemia took a transient course and did not recur (Figure 2). He was well conscious and discharged on the fourteenth hospital day without any complaints.

In order to evaluate the cause of the hypercalcemia, additional examinations were performed. Laboratory data on the second hospital day (also showed in Table) was as follows; intact PTH of $12 \mathrm{pg} / \mathrm{mL}$ (normal range: 10 - 65), PTHrP of $<1.0 \mathrm{pmol} / \mathrm{L}$ (normal range: $<1.1$ ), 1,25$(\mathrm{OH})_{2} \mathrm{D}_{3}$ of $32.1 \mathrm{pg} / \mathrm{mL}$ (normal range: 20 - 60), calcitonin of $77 \mathrm{pg} / \mathrm{mL}$ (normal range: 15 - 86), ACE of 5.1 $\mathrm{U} / \mathrm{L}$ (normal range: 8.3 - 21.4), SCC of $6.1 \mathrm{mg} / \mathrm{mL}$ (normal range: $<1.5$ ), CYFRA $5.8 \mathrm{ng} / \mathrm{mL}$ (normal range: $<3.5$ ) and NSE $12.7 \mathrm{ng} / \mathrm{mL}$ (normal range: $<10$ ). Some of the serum tumor markers were elevated, however that was considered to be a result of renal impairment. As the renal function improved, the tumor marker decreased within normal level on the tenth day. There were no evidence of malignancy in chest $\mathrm{CT}$, pharyngoscope and esophagogastroduodenoscopy.

Then we examined the characteristics of the hot spring. The fluid contains much $\mathrm{Ca}$ of $240 \mathrm{mg} / \mathrm{dL}$, which is very high concentration, compared with that of fresh water $(1.5 \mathrm{mg} / \mathrm{dL})$ and sea-water $(58 \mathrm{mg} / \mathrm{dL})$. It is considered that the hypercalcemia was due to the absorption of $\mathrm{Ca}$ contained in the fluid through the alveoli. 


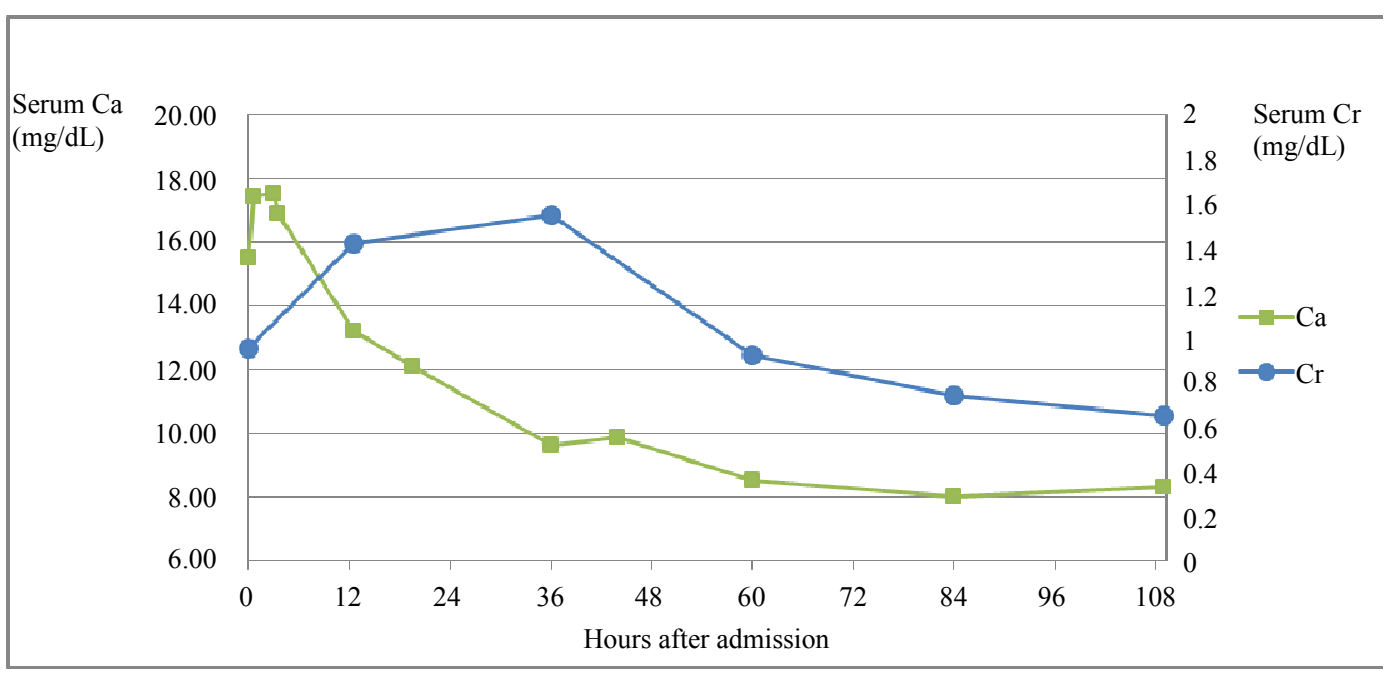

Figure 2. Clinical course of serum $\mathrm{Ca}$ and $\mathrm{Cr}$. Unit conversion of $\mathrm{Ca}$ is as below; $\mathrm{mg} / \mathrm{dL}=4 \times \mathrm{mEq} / \mathrm{L}$.

\section{Discussion}

Near-drowning is a life-threatening accident and care for hypoxia is the mainstay of its treatment [2]. When a drowning patient can no longer hold the breath, some amount of water is aspirated into the airways. As a reflex response, coughing occurs and sometimes laryngospasm occurs. Water in the alveoli causes surfactant dysfunction and washout. This disrupts the integrity of the membrane, increases its permeability, and exacerbates fluid, plasma, and electrolyte shifts [3]. The combined effects of fluids in the lungs, loss of surfactant, and increased permeability of the alveolar-capillary membrane result in hypoxia.

It is well known that sea-water drowning and fresh water drowning bring different clinical conditions. It has only been emphasized the importance of discriminating the two. Sea-water drowning causes hypernatremia and dehydration. On the other hand, fresh water drowning causes hyponatremia and hemolysis [4]. These electrolyte changes in near-drowning victim are seldom thought to be a cause of death [2]. Hypercalcemia in near-drowning victim is a rare complication except for a certain situation $[1,5,6]$.

The patient's hypercalcemia had already appeared on admission. It was characterized by acute onset, transient course and no recurrence. In general, malignant tumor and primary hyperparathyroidism were responsible for almost of hypercalcemia [7], but there was no sign or laboratory finding suggestive of these diseases. There was no family history, medications or medical history that could cause hypercalcemia. The hot spring water contained $240 \mathrm{mg} / \mathrm{dL}$ of $\mathrm{Ca}$, so his hypercalcemia was probably due to absorption of $\mathrm{Ca}$ from aspirated fluid through the alveoli. It was supposed that gastrointestinal absorption of $\mathrm{Ca}$ played only a little part, because nasogastric tube was inserted soon after his admission and amount of fluid was aspirated. Milk-alkali syndrome, whose pathogenesis is excess intake of $\mathrm{Ca}$, requires more than 4 gram of $\mathrm{Ca}$ intake regularly $[8,9]$.

Modell et al. demonstrated in experimental model that change of sodium concentration occured within 5 minutes after injection of fresh water in alveoli [10]. Another case reports show that $\mathrm{Ca}$ absorption through alveoli precedes that from gastrointestinal tract $[1,5]$. Analysis of the urine during the first 12 hours revealed that urinary excretion of Ca was $2013 \mathrm{mg}$. That is equal to about $83 \mathrm{~mL}$ of hot spring fluid. Oehmichen et al. reported that drowning led to an aspiration of only $2-4 \mathrm{~mL}$ water $/ \mathrm{kg}$ [11]. If the same process occurred in the present case, total amount of aspirated fluid was about $130-260 \mathrm{~mL}$.

Hypercalcemia induces functional disturbances in kidney, central nervous system, gastrointestinal tract and cardiovascular system [8]. Severe hypercalcemia, defined as serum Ca more than $14.0 \mathrm{mg} / \mathrm{dL}$, often causes polyuria and alters mental status. Arrhythmia is also the manifestation of hypercalcemia and lethal arrhythmia in a near-drowning victim in the Dead Sea, in which Ca concentration is $1709 \mathrm{mmol} / \mathrm{L}$, which have been reported [1].

Serum Ca level was the most predictable factor than other electrolyte abnormalities in near-drowning in the Dead Sea and Ca levels of more than $15.5 \mathrm{mg} / \mathrm{dL}$ were significantly related to mortality [12]. Yagil et al. reported that serum magnesium level was also important in a near-drowning victim [1]. Although serum magnesium level on admission was not measured in our case, it seemed to be normal for the hot spring water containing much less magnesium. In managing hypercalcemia, volume repletion and induction of saline diuresis followed by loop diuretics are keys to therapy. Bisphosphonates are often used to malignancy induced hypercalcemia, but it takes 2 to 4 days to get its effect [13]. Calcitonin is an effective adjuvant and has a rapid onset, but its effect is 
transient and limited. It is difficult to know the exact reason of renal impairment in the present case, but hypercalcemia could have affected the renal function. The renal function improved as the serum $\mathrm{Ca}$ was normalized.

Here we report a case of acute and severe hypercalcemia in a near-drowning victim in hot spring due to the excessive $\mathrm{Ca}$ absorption mainly through the alveoli.

\section{REFERENCES}

[1] Y. Yagil, R. Stalnikowicz, J. Michaeli and P. Mogle, "Near-Drowning in the Dead Sea," Archives of Internal Medicine, Vol. 145, No. 1, 1985, pp. 50-53. http://dx.doi.org/10.1001/archinte.1985.00360010070009

[2] J. H. Modell, "Drowning and Near-Drowning," In: A. S. Fouci and E. Braunwald, Eds., Principles of Internal Medicine, McGraw-Hill, Inc., New York, 1998, pp. 25552557.

[3] D. Szpilman, J. J. M. L. Bierens, A. J. Handley and J. P. Orlowski, "Drowning," New England Journal of Medicine, Vol. 366, No. 22, 2012, pp. 2102-2110. http://dx.doi.org/10.1056/NEJMra1013317

[4] "Drowning," Lancet, Vol. 292, No. 7565, 1968, pp. 441442. http://dx.doi.org/10.1016/S0140-6736(68)90475-3

[5] R. E. Fromm, "Hypercalcemia Complicating an Industrial Near-Drowning," Annals of Emergency Medicine, Vol. 20, No. 6. 1991, pp. 669-671. http://dx.doi.org/10.1016/S0196-0644(05)82392-3

[6] T. Machi, T. Nakazawa, Y. Nakamura, K. Okeie, Y. Horita, H. Hirai, H. Miyamori, Y. Saito and S. Kitagawa,
"Severe Hypercalcemia and Polyuria in a Near-Drowning Victim," Internal Medicine, Vol. 34, No. 9, 1995, pp. 868-871. http://dx.doi.org/10.2169/internalmedicine.34.868

[7] R. Ziegler, "Hypercalcemic Crisis," Journal of the American Society of Nephrology, Vol. 12, 2001, pp. S3-S9.

[8] M. J. Smogorzewski, R. K. Rude and A. S. L. Yu, "Disorders of Calcium, Magnesium, and Phosphate Balance," In: B. M. Brenner, Ed., The Kidney, Saunders Inc., 2007, p. 697.

[9] B. I. Medarov, "Milk-Alkali Syndrome," Mayo Clinic Proceedings, Vol. 84, No. 3, 2009, pp. 261-267. http://dx.doi.org/10.4065/84.3.261

[10] J. H. Modell, M. Gaub, F. Moya, B. Vestal, H. Swarz, "Physiologic Effects of Near Drowning with Chlorinated Fresh Water, Distilled Water and Isotonic Saline," Anestheology, Vol. 27, No. 1, 1966, pp. 33-41.

[11] M. Oehmichen, R. Hennig and C. Meissner, "Near-Drowning and Clinical Laboratory Changes," Legal Medicine, Vol. 10, No. 1, 2008, pp. 1-5. http://dx.doi.org/10.1016/j.legalmed.2007.05.007

[12] A. Porath, M. Mosseri, I. Harman, I. Ovsyshcher and A. Keynan, "Dead Sea Water Poisoning," Annals of Emergency Medicine, Vol. 18, No. 2, 1989, pp. 187-191. http://dx.doi.org/10.1016/S0196-0644(89)80112-X

[13] A. F. Stewart, "Hypercalcemia Associated with Cancer," New England Journal of Medicine, Vol. 352, No. 4, 2005, pp. 373-379. http://dx.doi.org/10.1056/NEJMcp042806 